УДК 630.614.841.3

DOI $10.21661 / \mathrm{r}-115271$

\title{
T.A. Нгуен
}

\section{АНАЛИЗ СОДЕРЖАНИЯ И СОСТОЯНИЯ ПРОТИВОПОЖАРНОЙ БЕЗОПАСНОСТИ ЛЕСНОГО ХОЗЯЙСТВА}

Аннотация: в статье изучены основные моменты пожарной безопасности лесного хозяйства России. Рассмотрен порядок действий соответствующии служб и поведение населения во время пожароопасного периода. В ходе изучения данной проблемы выявлено как несоверменство и уязвимые места системы предупреждения крупных пожаров, так и несовершенство законодательной стороны вопроса, а также указаны их причины.

Ключевые слова: пожарная безопасность, пожароопасный период, лесные пожары.

\section{T.A. Nguen}

\section{THE ANALYSIS OF IMPROVEMENT AND MAINTENANCE OF FIRE SAFETY OF FORESTRY}

Abstract: the article has studied the main points of fire safety of forest in Russia. The order of actions of the relevant services and the people behavior during the fire season. Examining this issue, the author revealed shortcomings and vulnerabilities of large fire prevention system and imperfection of the legislative side of the issue and stated their reasons.

Keywords: fire safety, fire-risk period, forest fires.

Главная проблема, которая существует в лесном хозяйстве это лесные пожары. Исторически лесные пожары в России были национальным бедствием, которые уносили как человеческие жизни, так и причиняли большой ущерб окружающей среде и экономике страны. Исходя из этого, первоочередной задачей 
является повышение требований пожарной безопасности со стороны государственной власти и местного самоуправления, так и формирование культуры поведения отдельного человека [2, с. 74-77; 7, с. 37-47].

Целью настоящей работы было проанализировать противопожарное состояние лесов в России и дать оценку пожарной безопасности в пожароопасный период.

История лесных пожаров на Руси отражается в летописях, записках дипломатов и путешественников. Как правило, этому стихийному бедствию предшествовали засухи, которые повторялись с периодичностью в 3-5 лет. Из древних документов известно, что их масштаб был неодинаков. Указываются периоды, когда засухами были охвачены небольшие районы, но также есть свидетельства катастрофических засух и сопутствующих им лесным пожарам, когда в огне оказывались целые регионы. Такие крупные засухи и лесные пожары, впервые упоминающиеся в документах, зафиксированы в 994, 1042, 1092 годах. В последующие столетия в исторических документах регулярно отмечаются это стихийное бедствие, но, тем не менее, мер по борьбе никаких не принималось. По этой причине продолжительность лесных пожаров исчислялась месяцами - их никто не тушил, и потому они горели до тех пор, пока не гасли по естественным причинам.

Борьбу с лесными пожарами стали вести уже при советской власти в 30-х годах XX века, когда появились необходимые технические средства и осознание значимости этой борьбы [4, с. 142].

В настоящее время Стратегия национальной безопасности страны предлагает повысить в российском обществе социальную значимость пожарной безопасности, формировать её культуру в контексте общей культуры общества, при этом нужно учитывать уже принятые законодательные основы этого вида безопасности.

В Российском законодательстве существует Федеральный закон от 21 декабря 1994 г. №69-Ф3 «О пожарной безопасности», который содержит термин «особый противопожарный режим». Данное понятие включает в себя требования 
пожарной безопасности, которые устанавливаются органами государственной власти или органами местного самоуправления, если повышается пожарная опасность [9, с. 2].

Основными задачами охраны лесов от пожаров являются предупреждение лесных пожаров, их обнаружение, ограничение распространения и тушение, выполнение которых обеспечивается проведением комплекса противопожарных мероприятий, разработанных ранее или разрабатываемыми заново для изменившихся условий в каждом лесхозе с учетом действующих требований правил пожарной безопасности в лесах (ППБ) [3, с. 8]. В настоящее время существуют разнообразные противопожарные профилактики, которые сводятся к 3 основным моментам:

1) предупреждение возникновения лесных пожаров;

2) ограничение распространения лесных пожаров;

3) организационно-технические мероприятия, которые обеспечивают пожарную устойчивость лесного фонда.

Предшествует этим мероприятиям введение пожароопасного периода. Обычно он начинается в Средней полосе России с момента таяния снега и заканчивается с наступлением устойчивой дождливой погоды. Длится он с апреля по ноябрь. На конкретной территории того или иного региона, начало его устанавливается органами местного самоуправления и зависит от климатических условий данной местности. Требования безопасности на момент установления пожароопасного периода установлены:

1. Федеральным законом от 22 июля 2008 г. №123-Ф3 «Технический регламент о требованиях пожарной безопасности» [10, с. 9].

2. Правилами противопожарного режима в Российской Федерации, утверждёнными постановлением Правительства РФ от 25 апреля 2012 г. №390 [6, c. 14].

При наступлении пожароопасной ситуации, которая связана обычно с длительным отсутствием осадков, органы государственной власти и местная администрация вводит на своей территории противопожарный режим. В дальнейшем 
работодатели обязаны подготовить законодательно свою организацию к такому периоду. Руководители организации издают приказы об установлении противопожарного режима на подведомственной территории, а также приказы о назначении ответственных лиц по пожарной безопасности.

В пожароопасный сезон необходимо соблюдать противопожарные профилактические меры, предупреждающие возникновение лесных пожаров. Эти меры включают в себя регулирование посещаемости лесов, а также проведение пропаганды и агитации среди населения.

Ещё одним немаловажным аспектом являются меры по ограничению распространения пожаров. Они заключаются в повышении пожароустойчивости насаждений, что достигается за счёт санитарных рубок, рубок ухода, очистки леса от захламлённости, создания противопожарных барьеров, поддержание в должном состоянии сети дорог, а также контролируемое выжигание не покрытых лесной растительностью участков.

И последней составляющей противопожарных профилактических мер являются организационно-технические мероприятия, повышающие пожарную устойчивость лесного фонда. Смысл этих мероприятий заключаются: в закреплении участков леса за населенными пунктами, организациями, предприятиями, кроме того местное население должно быть подготовлено к работам по обнаружению и тушению пожаров.

Недостаточность исполнения вышеуказанных мер явно отразилась в 2010 году, когда во многих субъектах Российской Федерации свирепствовали лесные пожары. Основная причина недостаточной охраны лесов от пожаров являлось ликвидация лесной охраны в период 2007 по 2011 года. Лесные пожары летом 2010 года показали, что никакие другие структуры ни МЧС, ни военные, не имеющие знаний и опыта в тушении лесных пожаров не могут должным образом справляться с данным стихийным бедствием. Лишь после этой чрезвычайной ситуации было принято решение о возвращении лесной охраны, что отражено в изменении от 18 июля 2011 года №242-Ф3, внесенные в Лесной кодекс РФ. 
Ещё одной причиной возникновения крупных лесных пожаров и расширение площади их распространения стало расформирование «Центральной базы авиационной охраны лесов». Данное решение способствовало снижению возможности быстро перебросить соответствующих специалистов и технику в районы крупных возгораний.

Кроме этих причин неудовлетворительной охраны лесов от пожаров есть и другие. Они касаются, прежде всего, организационных мер, когда органы власти попустительски относятся к лесам в пожароопасный период. В этот период от властей требуется ограничить доступ населения в леса. Это выражается в нехитрых и простых действиях: ремонт заграждений, препятствующих несанкционированному въезду автотранспорта в пожароопасный период, установление информационных щитов на пожароопасную тему и т. д. Ко всему прочему необходимо организовывать профилактические мероприятия, способствующие снижению риска возникновения лесных пожаров [5, с. 128-131].

Кроме организационных мер, со стороны власти необходимы законодательные меры. На федеральном уровне должны быть приняты нормы, о привлечение к ответственности должностных лиц, которые отвечают за противопожарное состояние в лесах и допустивших, крупные лесные пожары.

Ещё один опрометчивый поступок государственной власти - это отказ от государственных лесхозов с передачей частному лесопользователю ответственности за охрану и воспроизводство лесов. В данном случае все мероприятия по пожарной охране леса должен проводить арендатор. Иногда данные действия не всегда приводят к положительным результатам, в виду отсутствия специалистов в области лесного хозяйства. Охрана лесов от пожаров всегда основывалась на принципах раннего обнаружения и ликвидации начальной стадии развития возгорания. Патрульные лесники могли быстро ликвидировать, либо предотвратить распространение очага возгорания первичными средствами пожаротушения, вовремя заметив его. Раннее обнаружение и прибытие на место возгорание неболь- 
шой группы человек позволяло бороться с огнём на труднодоступных территориях. Если нет данной службы, то никакая техника не поможет в тушении крупного лесного пожара, что показал опыт 2010 года [8, с. 26; 1, с. 118].

Таким образом, противопожарное состояние лесов далеко от идеального. Чтобы не допустить повторно крупные лесные пожары правительству необходимо усовершенствовать нормативно-правовую базу, касаемую охраны лесов от пожаров, организовать контроль за противопожарным состоянием лесов. Кроме того, необходимо увеличить объёмы финансирования для обновления материально-технической базы региональных противопожарных служб и возрождения отраслевой науки, особенно в подготовке специалистов в области лесного хозяйства.

\section{Сиисок литературы}

1. Гринин А.С. Экологическая безопасность. Защита населения и территорий при чрезвычайных ситуациях / А.С. Гринин, В.Н. Новиков. - М.: ФаирПреcс, 2000. - 336 c.

2. Зарецкий А.Д. Пожарная безопасность как составная часть стратегии национальной безопасности России. Угрозы и безопасность / А.Д. Зарецкий, 2010 - T. 1. - №58. - C. 74-77.

3. Лесной кодекс Российской Федерации от 4 декабря 2006 г. [Электронный pecypc]. - Режим доступа: http://www.consultant.ru

4. Матвеев П.М. Лесная пирология / П.М. Матвеев, А.М. Матвеев. - Красноярск: СибГТУ, 2002. - 300 с.

5. Паламарчук С.В. Неудовлетворительная охрана лесов от пожаров в субъектах Российской Федерации как одна из самых глобальных проблем современности: причины, пути решения. Охрана лесов от пожаров. Пробелы в российском законодательстве. - М., 2012. - №2. - С. 128-131.

6. Правила противопожарного режима в Российской Федерации, утверждёнными постановлением Правительства РФ от 25 апреля 2012 г. №390 [Электронный ресурс]. - Режим доступа: http://www.mchs.gov.ru 
7. Серебренников Е.А. Пожарная безопасность - составная часть национальной безопасности // Материалы VIII Всероссийской научно-практической конференции по проблемам защиты населения и территорий от чрезвычайных ситуаций. - М., 2003. - С. 37-47.

8. Смирнов А.П. Лесная пирология: Учебное пособие / А.П. Смирнов, Е.С. Мельников. - СПб.: СПБ ГЛТА, 2006. - 60 с.

9. Федеральный закон от 21 декабря 1994 г. N 69-Ф3 «О пожарной безопасности» // [Электронный ресурс] / Режим доступа: http://www.consultant.ru /document/cons_doc_LAW_5438/

10. Федеральный закон от 22 июля 2008 г. №123-Ф3 «Технический регламент о требованиях пожарной безопасности» // [Электронный ресурс] / Режим доступа: http://base.garant.ru/12161584/

Нгуен Туан Ань - канд. техн. наук, преподаватель Института пожарной безопасности Министерства общественной безопасности Вьетнама, Социалистическая Республика Вьетнам, Ханой.

Nguen Tuan An - candidate of technical sciences, lecturer at the Institute of Fire Safety of Viet Nam Ministry of Public Security, Socialist Republic of Viet Nam, Hanoi. 